\title{
CRITERIA TO DISTINGUISH BETWEEN PERIGLACIAL, PROGLACIAL AND PARAGLACIAL ENVIRONMENTS
}

\author{
Olav Slaymaker \\ University of British Columbia, Department of Geography, Vancouver, Canada
}

Manuscript received: May 09, 2010

Revised version: February 14, 2011

\begin{abstract}
SLAYMAKER O., 2011. Criteria to distinguish between periglacial, proglacial and paraglacial environments. Quaestiones Geographicae 30(1), Bogucki Wydawnictwo Naukowe, Poznań, pp. 85-94, 9 Figs., 1 Tab. ISBN 978-8362662-39-5. ISSN 0137-477X. DOI 10.2478/v10117-011-0008-y.
\end{abstract}

AвSTRACT. Clarification of the differences between the terms periglacial, proglacial and paraglacial is based on consideration of their conventional definitions, and noting that the term "periglacial" is a function of process, "proglacial" is a function of location and "paraglacial" is a function of degree and mode of recovery from the disturbance of continental glaciation . Periglacial and proglacial environments are commonly viewed as being adjusted to contemporary process, though important questions have been raised about relict periglacial landscapes in this regard. Paraglacial environments are explicitly out of adjustment with contemporary process and retain in their configuration a glacial signature. All three concepts are seen to be essential to comprehensive understanding of glaciated environments. It is a nested set of concepts which overlap in the field but none of the terms is redundant. Criteria for differentiation of these cold environment descriptors are proposed.

KEYWORDS: periglacial, proglacial, paraglacial, disturbance regime

Olav Slaymaker, University of British Columbia, Department of Geography, Vancouver, British Columbia, Canada V6T 1Z2,e-mail: olav.slaymaker@ubc.ca

\section{Introduction}

Recently, it has become popular to invoke the term "paraglacial" as a descriptor of previously described periglacial and/or proglacial environments, with the underlying assumption either that the latter conventional geomorphic terms have been made redundant or that they are somehow less useful terms as descriptors of geomorphic environments (Mercier \& Etienne 2008, Iturrizaga 2008, Moreau et al. 2008). It seems important to revisit Ballantyne's (2002) definition of paraglacial, which subsumes all "non-glacial earth surface processes, sediment accumulations, landforms, land systems and landscapes that are directly conditioned by glaciation and deglaciation" to see whether there is still room for the conventional terms. The case that is made here is that there is still a need for all three terms, based on the fact that they are quite different concepts and are defined in quite different ways. Conventional definitions are as follows:

1. Periglacial environments are defined as those in which frost action and/or permafrost related processes dominate (French 2000, French \& Thorn 2006).

2. Proglacial environments are defined as those which are located close to the ice front of a glacier, ice cap or ice sheet (Penck \& Bruckner 1909). 
3. Paraglacial environments are defined in Church and Ryder (1972) as "non-glacial environments conditioned by glaciation" and this definition has been expanded by Ballantyne (2002) as above.

\section{Primary differentiators}

The differentiators of these environments are as follows: periglacial environments are defined primarily in terms of process and secondarily in terms of distinctive forms. The necessary condition for the existence of periglacial environment is intensive frost action and/or permafrost related processes. Patterned ground and pingoes are two of the many distinctive forms resulting from these processes (Table 1 ). The necessary condition for proglacial environments is ice-marginal location. Glaci-fluvial, glaci-lacustrine and glacimarine processes are the major processes of interest in such locations and they give rise to specific erosional and depositional forms. A dynamic system recovering from the disturbance of glaciation is the primary definition of a paraglacial system. Paraglacial environments are defined neither by process nor location but by trajectory from proglacial to non-glacial environment. That trajectory is also scale dependent, as discussed by Church \& Slaymaker (1989), such that small sub-systems have achieved adjustment with their non-glacial environment whereas larger sub-systems are still in recovery mode (Church 2002). At the scale of the landscape the paraglacial environment is still in transition and can be characterized as a disturbance regime (Hewitt 2002).
The case to be put here is that the term paraglacial environment should be restricted to landforms, land systems and landscapes that are recovering from glacial disturbance and relict landforms that provide evidence of the recovery process in the past. In the classic paper by Church \& Ryder (1972), the examples provided were drawn from Baffin Island (the Ekalugad valley), which is still in the process of recovering from glaciation, and from interior British Columbia (inactive, raised alluvial fans) which evidence the completion of the process of recovery of those landforms by early-mid-Holocene. It should be noted that, in the case of Ekalugad valley, the environment is not only paraglacial (early stage of recovery), but it is also proglacial and periglacial. This observation does not make any one of the three adjectives redundant; they draw attention to three different aspects of the environment.

\section{Implications for identifying periglacial and proglacial environments}

There is no doubt that there is an unnecessary amount of confusion in the literature with respect to the use of these terms, if only on the grounds that their definitions have varied over time (Iturrizaga 2003).

\section{Periglacial}

The original definition of periglacial focused on location, namely a zone around the edge of ice sheets (Lozinski 1912, French 2000). There is gen-

Table 1. Criteria for differentiation of cold environments

\begin{tabular}{|c|c|c|c|c|}
\hline \multirow{2}{*}{ Environment } & \multicolumn{4}{|c|}{ Criteria } \\
\cline { 2 - 5 } & $\begin{array}{c}\text { Transitional in } \\
\text { Space/Time }\end{array}$ & Location & Process & Form \\
\hline Paraglacial & $\begin{array}{c}\text { Degree of } \\
\text { recovery from } \\
\text { glaciation }\end{array}$ & Uplands & Non-glacial & Storage dominant \\
\hline Proglacial & & Ice-marginal & $\begin{array}{c}\text { Glaci-lacustrine } \\
\text { Glacimarine }\end{array}$ & Erosional \\
\hline Periglacial & & Freeze-thaw & Patterned ground \\
permafrost & Pingoes \\
\hline
\end{tabular}


eral agreement that intense frost activity and/or permafrost related processes is now the primary criterion (French 2007). There is a strong relation between contemporary processes and forms in periglacial environments to such an extent that the presence, for example, of relict ice wedges and pingo structures in older sediments allows the inference of the existence of former periglacial environments. The most distinctive periglacial landforms are associated with permafrost and include tundra polygons (Fig. 1), pingoes and palsas and thermokarst features where permafrost is thawing.

In areas of intense frost activity, coarse, angular rock debris, tors and a wide variety of patterned ground are formed. Periglacial processes are effective in breaking down bedrock through frost action and cryogenic weathering. (e.g. French \& Guglielmin 2000) and in forming distinctive local scale forms, particularly through heaving and sorting processes in situ. They are not, however, notably effective in evacuating those sediments so as to make them available for fluvial transport and deposition. Consequently, periglacial landforms are somewhat subdued in the landscape and their preservation in the geological record is limited. Two notable exceptions to this generalization are the extensive periglacial "head" and stratified slope deposits of northwestern Europe (DeWolf 1988) and the remarkable, still poorly understood, phenomenon of the cryoplain (Washburn 1979).

It is worth noting that proximity to glaciers is irrelevant to the definition. Periglacial systems

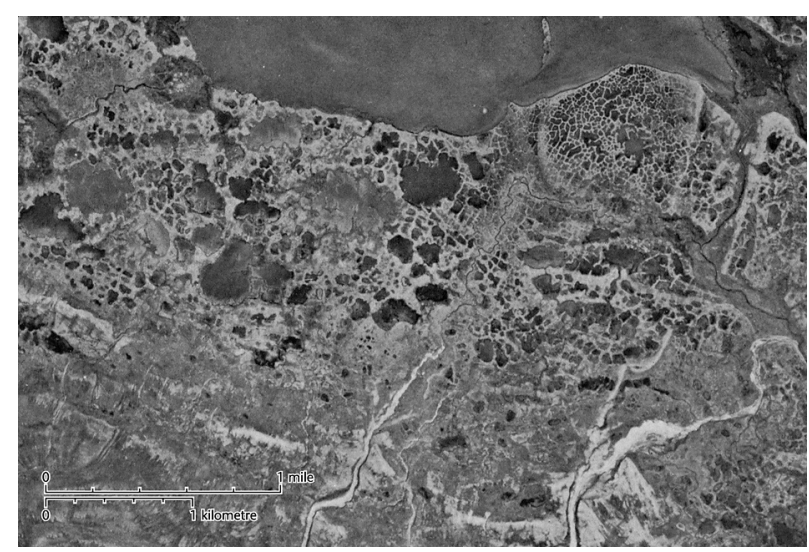

Fig. 1. Low centre tundra polygons, central Bathurst Island, Nunavut, a characteristic periglacial landform and landscape. NTS Map Sheet 68H; air photo designation A16203; photo courtesy of the National Air Photo Lab, Ottawa can be found in (a) the polar deserts and semideserts of the high Arctic; (b) the tundra zone; (c) the boreal forest zone; $(\mathrm{d})$ the maritime and continental sub-arctic; and (e) mid- and low latitude alpine regions (French 2007).

\section{Proglacial}

"Ice marginal" is perhaps the best descriptor of proglacial environments (Embleton-Hamann 2004). Location immediately in the front of glaciers, ice caps and ice sheets defines a proglacial environment. Such environments are adjusted to the average regime of fluvial, lacustrine or marine processes that occur immediately adjacent to the ice. The hydrology of proglacial rivers exhibits a distinctive pattern of flow, both seasonally and diurnally. Moderate flood flows are common and extraordinary jokulhlaup floods occur in front of many glaciers. Sediment is therefore frequently entrained and fluvial sedimentary features evolve rapidly (Church \& Gilbert 1975). Glacifluvial proglacial erosional forms include drainage diversions and spillways; depositional forms include sandar and braided outwash fans and display distinctive facies (Benn \& Evans 1998, Evans et al. 2005).

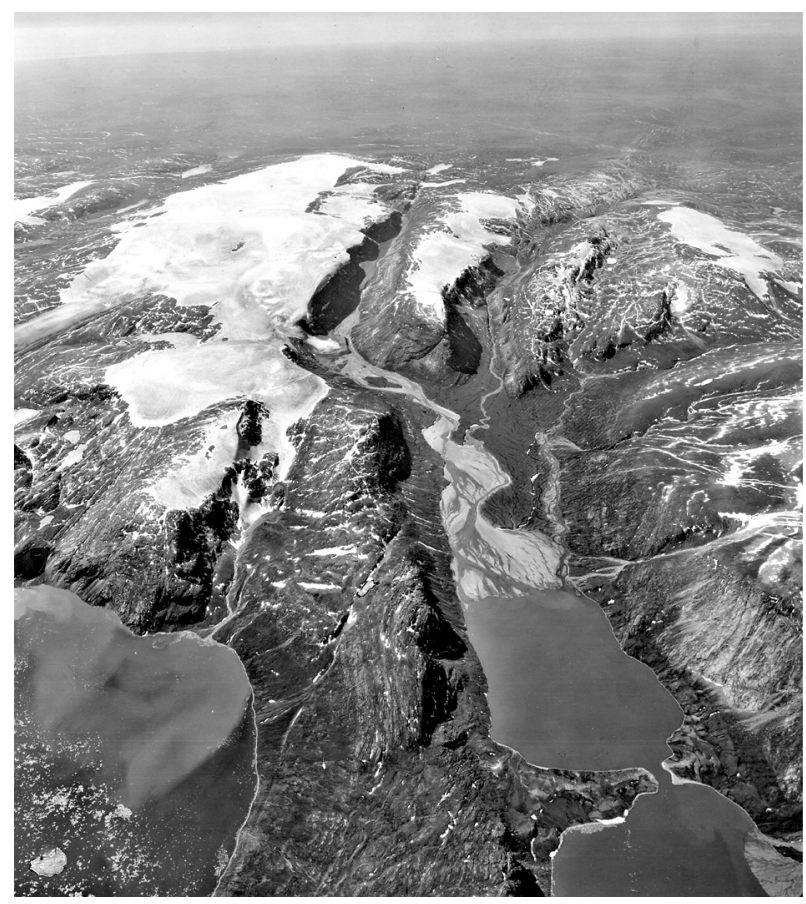

Fig. 2. Glaci-fluvial proglacial landscape of Ekalugad Valley, Baffin Island, Nunavut (from Church 1972) 

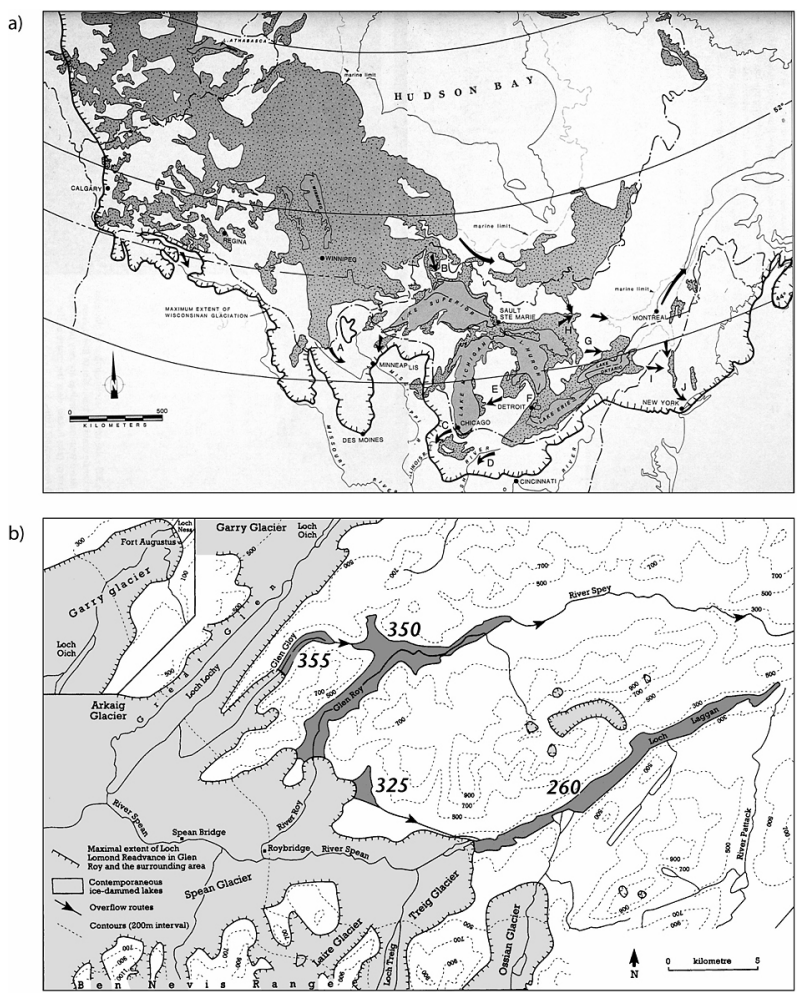

Fig. 3. Glaci-lacustrine proglacial environments: A. Area covered by proglacial lake sediment deposited during the retreat of the Laurentide ice sheet and the major drainage pathways draining the lakes into the Mississippi River and Atlantic Ocean (Teller 1987) and B. the parallel roads of Glenroy, Scotland (Sissons 1979)

One of the most extensive glaci-lacustrine environments was that of Lake Agassiz during the recession of the Laurentide Ice Sheet in North America (Fig. 3A) and one of the earliest documented glacilacustrine environments was that represented by the so-called "parallel roads" of Glenroy in Scotland (Fig. 3B). Contemporary glacilacustrine proglacial forms are responsible for strandlines and deltas (Hasholt et al. 2000) and display standard deltaic and lake bottom sediment facies (Benn \& Evans 1998).

Glacimarine proglacial forms are generally considered in two settings: the fjord environment (Fig. 4A), where sedimentation is influenced by tidewater or floating glaciers, rivers, slope and marine processes and the continental shelf (Fi. 4B) and deep ocean where sedimentation is dominated by grounded ice margins, ice shelves and open marine processes.
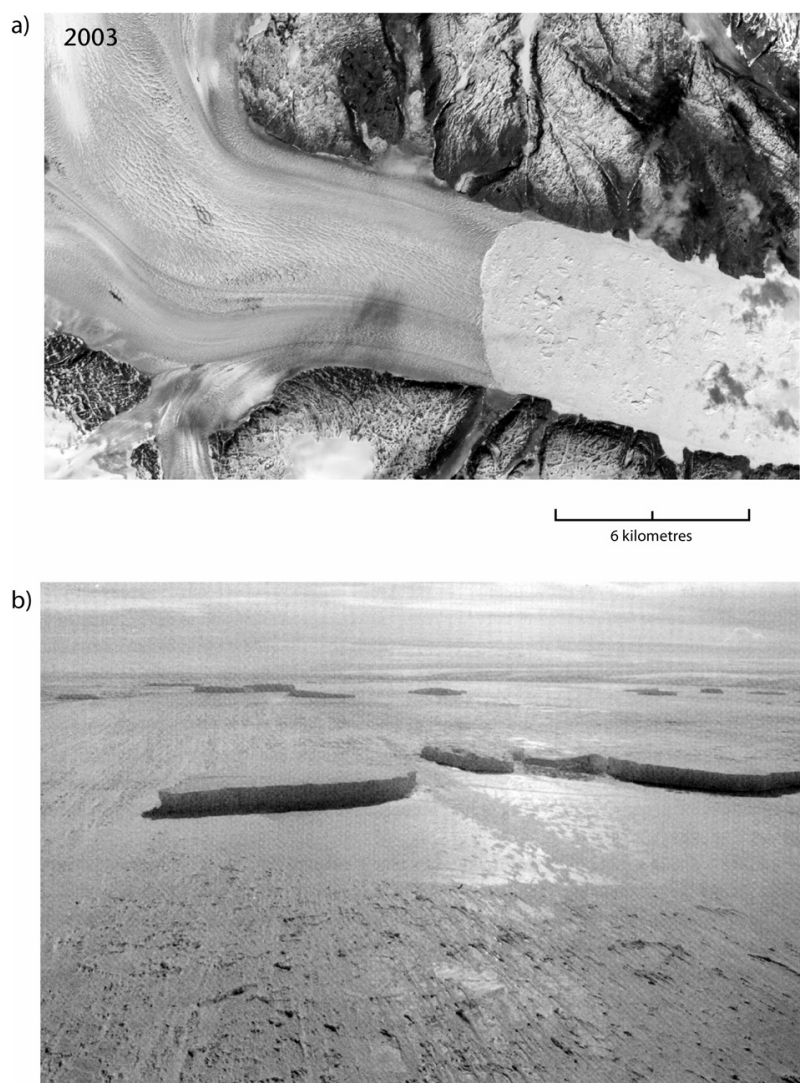

Fig. 4. Glaci-marine proglacial environments: A. the fjord environment, Helheim Glacier, Greenland indicates glacier to the left and pack ice to the right (Howat et al. 2005) and B. the continental shelf environment showing stranded icebergs on the eastern Weddell Sea continental shelf, Antarctica (Hambrey 1994). The actual thickness of these icebergs is unknown but they commonly achieve thicknesses of more than $300 \mathrm{~m}$

\section{Proglacial and periglacial systems as equilibrium systems}

It is commonly the case that proglacial and periglacial processes and forms are analysed under the assumption that they represent process-response system adjustments to governing conditions that are well understood as described in sections 3a. and 3b. above. Proglacial and periglacial landforms are indeed quite distinct if only for the reason that proglacial landforms, whether glaci-fluvial, glaci-lacustrine or glaci-marine necessarily result from sediment transport, whereas periglacial landforms are commonly confined to regolith-covered slopes. It is common for proglacial and periglacial environments to overlap. After all, the criteria of ice-marginal location and intensive freeze-thaw and/or permafrost related processes are in no sense exclusive of each other. 
The normal pattern is for geomorphologists to give precedence to proglacial. In other words if it is a proglacial/periglacial environment it is called proglacial. Similarly to call it periglacial nearly always implies that it is not actively proglacial.

Nevertheless, French (2007) has pointed out that most periglacial landscapes have recently emerged from under continental ice sheets and that they are still in the process of adjustment to contemporary thermal and precipitation regimes. In order to characterize "never glaciated periglacial terrain" he identified the landforms of Banks Island, N.W.T. and the Barn Mountains, Yukon Territory and demonstrated the large role of fluvial processes in those landscapes. Although most of the small scale features produced by periglacial processes are unambiguous, Andre (2003) has raised the interesting question whether periglacial regions evolve under periglacial conditions. The question is interesting for at least two reasons: it underlines the fact that periglacial regions have been subject to alternating warmer and colder climatic conditions during the Quaternary and secondly, it raises an issue which will resurface in the context of the paraglacial discussion below, namely whether periglacial environments at the landscape and land systems scale are also disturbance regime environments.
Thorn \& Loewenherz (1987) proposed a model of temporal relationships between glacial, paraglacial and periglacial landscapes under changing energy conditions. Assumptions involved in this model include the constant energy condition, or equilibrium, of periglacial landscapes.

They emphasized the extent to which the evolution of periglacial forms at local scale is superimposed on the longer term evolution of periglacial landscapes which, at any given time, may have differing proportions of glacial, fluvial and periglacial elements. This suggests that there is a spatial scale of landform to which the periglacial term is most applicable and that we should perhaps be more sparing in our use of the term to describe whole landscapes.

By contrast with these considerations on periglacial process-form relations, proglacial environments are always considered as quasiequilibrium systems. Two reasons are that the high energy environment which characterizes the ice marginal location effectively destroys the evidence of previous regimes and, when the ice recedes, the proglacial forms and processes gradually merge into the uniquely paraglacial landscape.

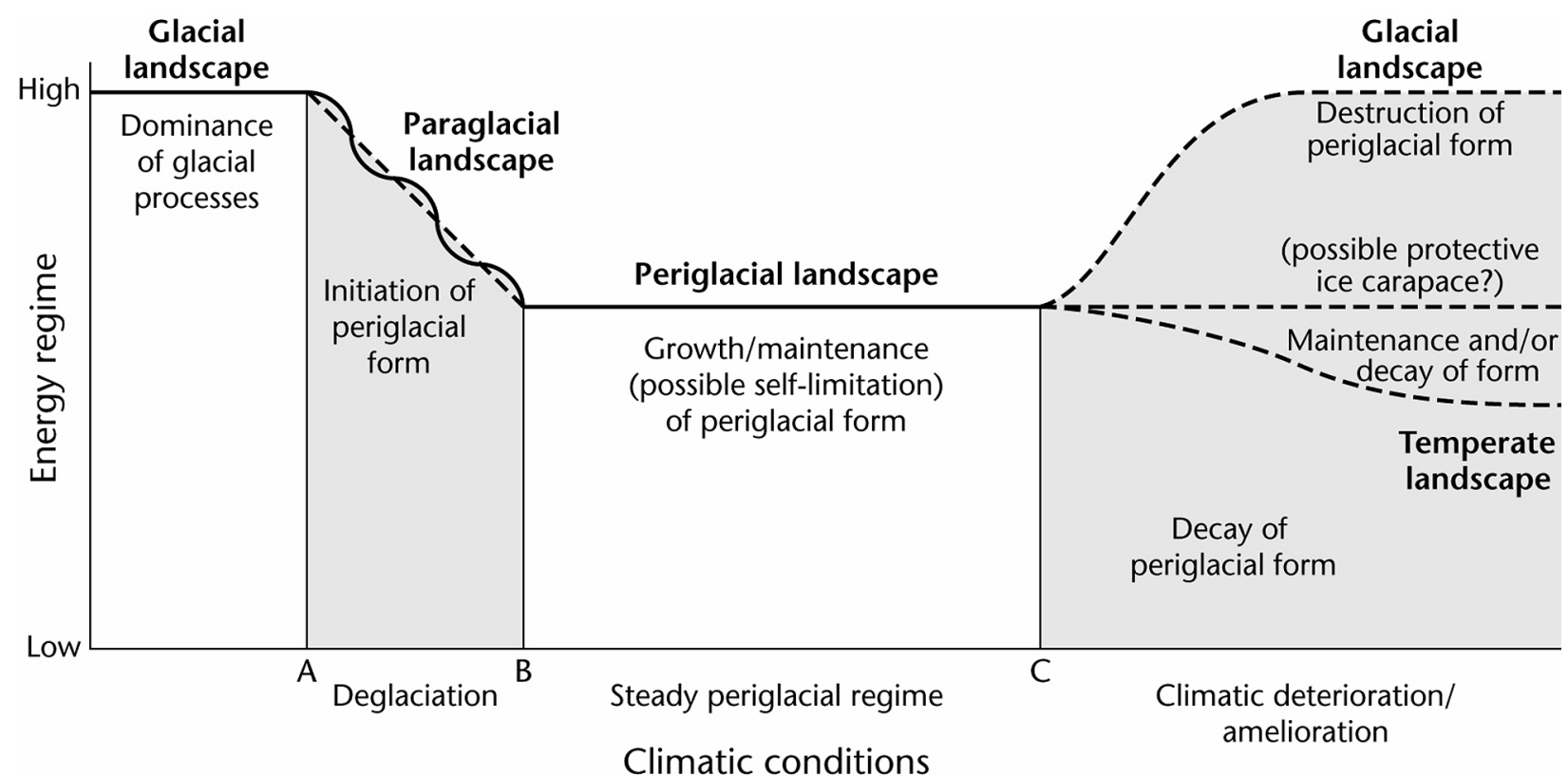

Fig. 5. Conceptual model of glacial-paraglacial-periglacial environmental evolution. (Thorn and Loewenherz 1987) 


\section{Implications for identifying paraglacial environments}

In accepting Ballantyne's (2002) modified definition of paraglacial as "non-glacial earth surface processes, sediment accumulations, landforms, land systems and landscapes that are directly conditioned by glaciation and deglaciation", the criteria for identification of paraglacial environments were dramatically extended beyond those envisaged by Church \& Ryder (1972).

Not only debris cone, alluvial fan and valley fill deposits (Fig. 6) are now included but rock slopes (Johnson 1984); sediment-mantled slopes (Curry 2000); glacier forefields (Matthews et al. 1998); glacilacustrine systems (Shaw \& Archer 1979) and coastal systems (Forbes \& Syvitski 1994) have become part of the paraglacial concept. Even before this expansion of the Church and Ryder definition, criteria were difficult to elaborate given that all non-glacial earth surface processes, including mass movement, fluvial, lacustrine, aeolian, coastal and marine processes, were legitimately incorporated into the definition. Both Benn \& Evans (1998) and Ballantyne (2002) made the case that because there are no processes unique to paraglacial environments it would be better to think of paraglacial as re-

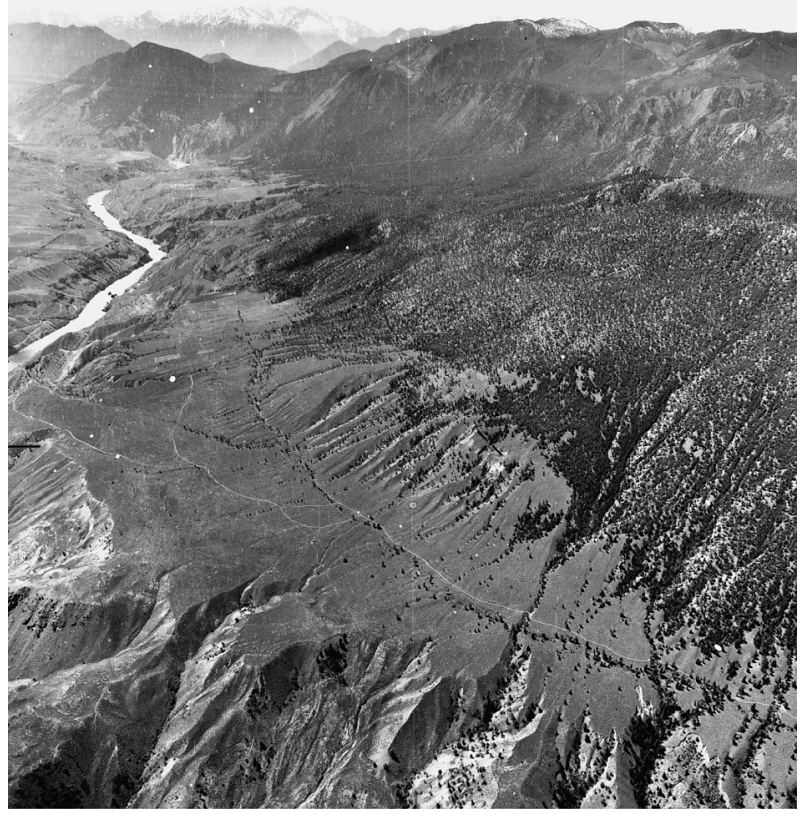

Fig. 6. Paraglacial valley fill deposits in central Fraser River basin, British Columbia (air photo 1087-46 B.C. by the Province of British Columbia) ferring to a period of time. Benn \& Evans (1998) proposed that paraglacial should be defined as "the period of rapid environmental adjustment following glacier retreat" and Ballantyne (2002) proposed to recast the definition of paraglacial to "the time scale over which glacially conditioned sediment stores are either exhausted or attain stability".

\section{Paraglaciation in a systems context}

Although these more recent proposals have merit, especially in the way in which Benn and Evans apply their definition to landforms, facies and land systems, they fail to emphasize the radical nature of the paraglacial concept. In order to make it clear that paraglacial environments require a systems context, Slaymaker (2009) has proposed a definition "a transitional landscape which is in the process of recovering from the disturbance of glaciation". This definition makes use of the terms "transitional" and "disturbance" (Hewitt 2006) which place the concept firmly in the realm of systems thinking. and makes it possible to adjust its application to systems of different spatial scale.

There are a number of implications of the adoption of the transitional landscape definition, as follows:

1. Paraglacial landforms and land systems will have different response and recovery times, depending on spatial scale, pre-existing system state, the extent of the glacial disturbance and the number and intensity of Holocene disturbances, whether hydroclimate or land use. Any characterization of environmental change in glaciated regions should attempt to ascertain the position of the paraglacial landform or land system in the recovery process

2. A consideration of styles of disturbance is needed

3. A metric to define response and recovery times is needed

4. In the long term, it may become possible to identify paraglacial landscapes within a panarchy framework (Holling 2001, Cammeraat 2002). 


\section{Response and recovery times}

Quantitative examples of response and recovery times of paraglacial systems from many parts of the world are now available (e.g. Ballantyne 2002, Mercier 2002). The evolution of paraglacial systems in British Columbia as a function of spatial scale is illustrated in Fig. 7.

This places the paraglacial discussion in a similar context to that of Wolman and Gerson (1978) on relative scales of time and effectiveness of climate in watershed geomorphology and of Hewitt (2006) on disturbance regime landscapes.

\section{Styles of disturbance}

The disturbance to which paraglacial landscapes refer is, of course, the Last Glacial Maxi-

a)

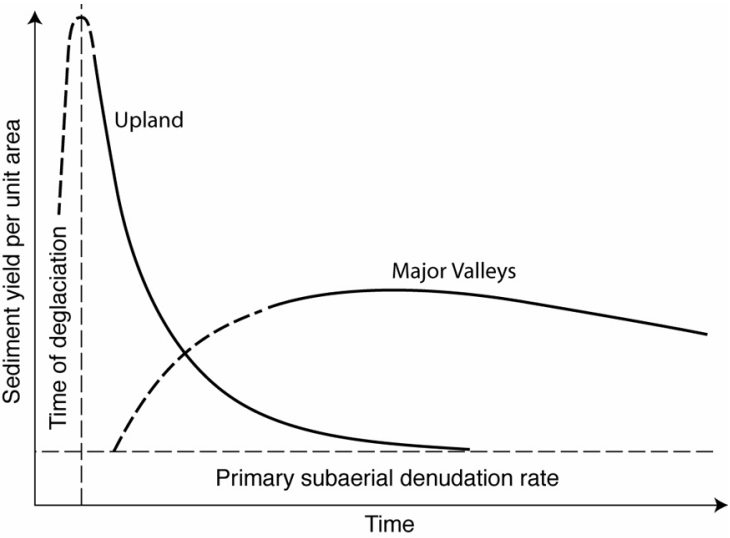

b)

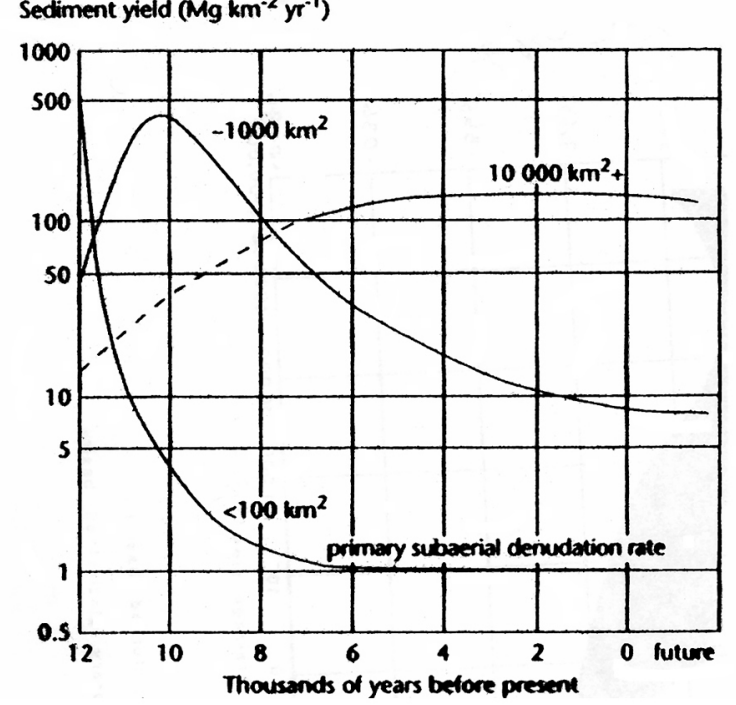

Fig. 7. Scale effects in paraglacial systems: A. uplands v. major valleys (Church \& Slaymaker 1989) and B. paraglacial response as a function of spatial scale (Church 1998) mum, which in British Columbia occurred around 14,500 years ago, but is thought to have ranged up to 20,000 years ago in Russia. There are however intervening disturbances, caused by relief changes (Fig. 8), hydroclimate changes, sea level changes and land use changes sensu lato which complicate the orderly recovery of the landscape. The example quoted in Fig. 8 concerns the glacierized Lillooet River basin in British Columbia The basin at all elevations below present glaciers is a paraglacial upland landscape whose orderly evolution has been interrupted by two massive slope failures in Quaternary volcanics and experienced subsequent disturbance by Neoglaciation and recent land use changes. The general model discussed by Church and Slaymaker (1989) needs

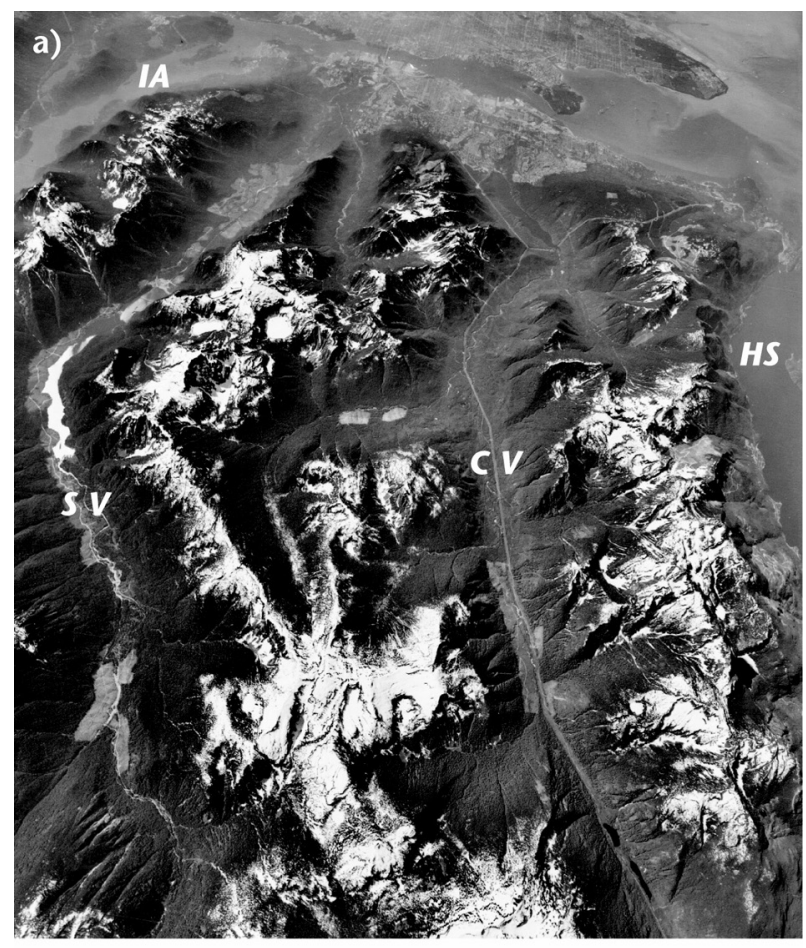

b)

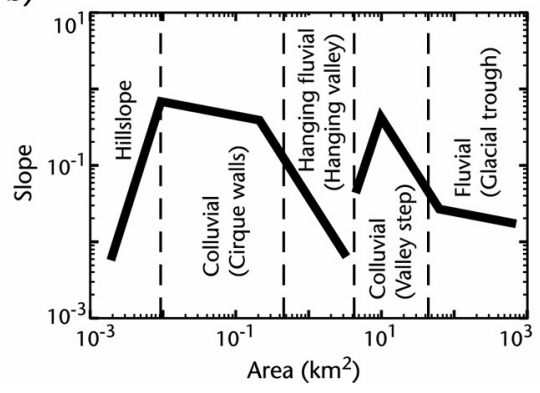

Fig. 8. Conceptual model of evolution of upland paraglacial landscape interrupted by massive failure of Quaternary volcanics (Friele et al. 2005), and potential Neoglacial and land use effects (Jordan \& Slaymaker 1991) 
to be qualified in relation to regional and site specific disturbances.

\section{The search for a metric}

Brardinoni \& Hassan (2006) have explored the use of geomorphic process domains to locate the degree of recovery from glaciation of mountain landscapes.

The paraglacial cirque landscape of the southern Coast Mountains of British Columbia provides a test case for the application of their methodology (Fig. 9). Brardinoni and Hassan demonstrate the profound discontinuity between the contemporary hillslope and fluvial domains caused by the continuing presence of well-defined cirques in the landscape. Geomorphic process domains are identified in a space defined by gradient and increasing area. In fluvial landscapes the process domains follow a regular pattern from high gradient mass movement-dominated small areas $(<1 \mathrm{ha})$ to doimantly fluvial processes at areal scales $>1 \mathrm{~km}^{2}$ and with gradients $<10 \%$. However, in glaciated landscapes, this regular progression is interrupted by the glacial/paraglacial topographic legacy of the cirque as well as (in the case of the B.C. Coast Mountains) the preglacil erosion surface into which the cirques have been carved. The resulting sequence of domains is described in Fig. 9. The scale at which the break in the slope-area relation occurs provides a new metric for assessing the degree of recovery of the landscape from glacial disturbance. Non-glacial processes conditioned by glaciation are hereby defined as the slope and channel processes conditioned by cirque glaciation. Putkonen et al. (2008) have recently added an interesting alternative approach to the quantitative assessment of landscape recovery from glaciation. They examined the mode of degradation of moraines in alpine, tropical and polar moraines.

\section{Paraglaciation and panarchy}

Panarchy is a metaphor designed to describe systems of ecosystems at varying spatial and temporal scales. The terminology developed for panarchy (Holling 2001) is entirely ecological and needs to be translated for the needs of geomorphology. Holling suggests that all systems consist of adaptive cycles which exist at a range of spatial scales. The term adaptive is self-evident in ecological systems; in geomorphic systems we often speak of self-regulating systems (Phillips 2003). Adaptive cycles are defined as consisting of four phases, namely exploitation, conservation, release and reorganization. A geomorphic analogue would be a glacial-interglacial cycle

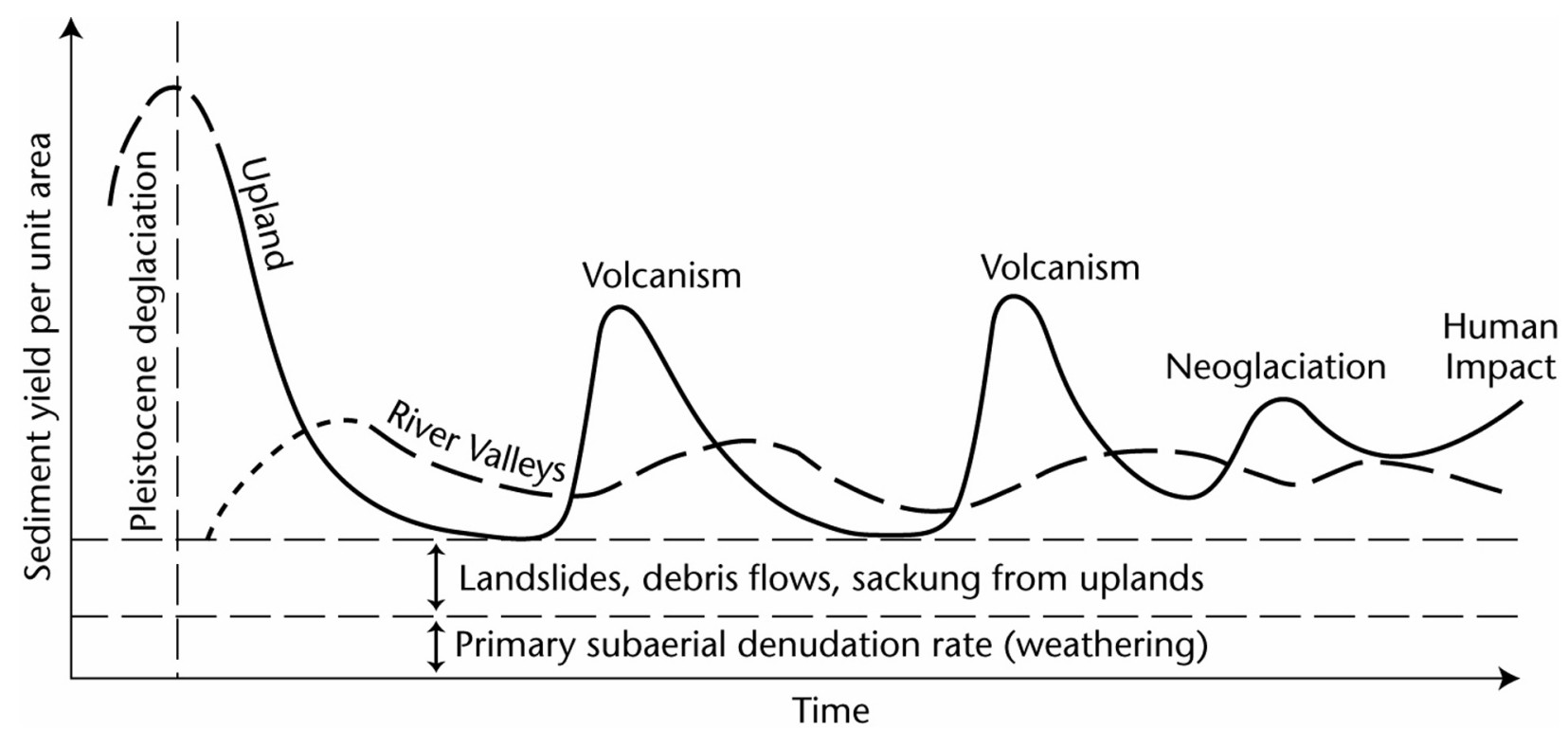

Fig. 9. The paraglacial cirque landscape: A. oblique photograph looking south towards the city of Vancouver (from Slaymaker \& Kelly 2007) and B. process domains defined by slope-area relations in the Capilano River basin (CV), Coast Mountains, British Columbia (Brardinoni \& Hassan 2006) 
characterized by both orderly evolution and system collapse. The duration of these phases of adaptation in ecological systems depends on three factors: wealth, connectivity and resilience of the system. A geomorphic translation could well speak of the intensity and extent of a glaciation, the connectivity of the erosion-sedimentation cycles and the time required for the recovery of the system during an interglacial. The panarchy metaphor has a fascinating flexibility in dealing with complex systems, whether ecological, socioeconomic or geomorphic (e.g. Cammeraat 1992).

\section{Conclusion}

Whereas proglacial landforms and landscapes can be viewed as quasi-equilibrium adjustments to the processes of erosion, sediment transport and deposition associated with ice marginal locations; periglacial landforms and landscapes can be viewed as equilibrium adjustments to intense freeze-thaw activity and permafrost processes. Hence the criteria for distinguishing between proglacial and periglacial landforms and landscapes can all be expressed in direct process-response terms.

Relict periglacial landscapes and paraglacial landforms and landscapes however can perhaps be best characterized as transitional disturbance regime landscapes.

In the case of paraglacial phenomena, new metrics indicating time since last disturbance, scale of disturbance and relation to drivers of change are needed. In general, the direction of change, from glacial to fluvial is understood. On the other hand, in the case of relict periglacial landscapes the direction of change is unclear.

\section{Acknowledgment}

A critical review by Colin Thorn has improved this text; however, the author is solely responsible for the final outcome.

\section{References}

ANDRE M.F., 2003. Do periglacial areas evolve under periglacial conditions? Geomorphology 52: 149-164.
Ballantyne C.K., 2002. Paraglacial geomorphology. Quaternary Science Reviews 21: 1935-2017.

Benn D.I., Evans D.J.A., 1998. Glaciers and Glaciation. Edward Arnold, London: 734.

BRARDINONI F., HASSAN M., 2006. Glacial erosion, evolution of river profiles and the organization of process domains in mountain drainage basins of British Columbia. Journal of Geophysical Research 11: DOI:10.1029/2005JF000358

CAmmeraAt L.H., 2002. A review of two strongly contrasting geomorphological systems within the context of scale. Earth Surface Processes and Landforms 27: 1201-1222.

Church M., Gilbert R., 1975. Proglacial fluvial and lacustrine environments. In: A.V. Jopling, B.C. MacDonald (eds). Glaciofluvial and glaciolacustrine sedimentation. Special Publication 23. Society of Economic Paleontologists and Mineralopists: Tulsa: 155-176.

Church M., Ryder J.M., 1972. Paraglacial sedimentation: a consideration of fluvial processes conditioned by glaciation. Geological Society of America Bulletin 83: 3072-3095.

Church M., Slaymaker O., 1989. Disequilibrium of Holocene sediment yield in glaciated British Columbia. Nature 337: 452-454.

Church M., 1972. Baffin Island sandurs: a study of arctic fluvial processes. Geological Survey of Canada Bulletin 216.

Church M., 1998. The landscape of the Pacific North West. In: D.L. Hogan, P.J. Tschaplinski, S. Chatwin (eds). Carnation Creek and Queen Charlotte Islands Fish/Forestry Workshop: applying 20 years of coast research to management solutions. B.C. Land Management Handbook. BC Forestry Research Branch, Victoria: 13-22.

Church M., 2002. Fluvial sediment transfer in cold regions. In: K. Hewitt et al. (eds). Landscapes of Transition. Kluwer Academic, Dordrecht: 93-118.

CURRY A.M., 2000. Observations on the distribution of paraglacial reworking of glacigenic drift in western Norway. Norsk Geografisk Tidsskrift 54: 139-147.

DeWolf Y., 1988. Stratified slope deposits. In: M.J. Clark (ed). Advances in Periglacial Geomorphology. John Wiley, Chichester: 91-110.

Embleton-Hamann C., 2004. Proglacial landforms. In: A.S. Goudie (ed). Encyclopedia of Geomorphology vol. 2. Routledge, London: 810-813.

Evans D.J.A., Clark C.D., Mitchell W.A., 2005. The last British Ice Sheet: a review of the evidence utilized in the compilation of the Glacial Map of Britain. Earth Science Reviews 70: 253-312.

Forbes D.L., SYvitSKI J.P.M., 1994. Paraglacial coasts. In: R.W.G. Carter, C.D. Woodroffe (eds). Coastal Evolution: Late Quaternary Shoreline Morphodynamics. Cambridge University Press, Cambridge: 373-424.

French H.M., Guglielmin M., 2000. Cryogenic weathering of granite, Northern Victoria Land, Antarctica. Permafrost and Periglacial Processes 11: 305-314.

FrenCH H.M., THORN C., 2006. The changing nature of periglacial geomorphology. Géomorphologie: relief, processus, environnement 3: 1-33.

FrenCH H.M., 2000. Does Lozinski's periglacial realm exist today? A discussion relevant to the usage of the term "periglacial". Permafrost and Periglacial Processes 11: 35-42.

French H.M., 2007. The Periglacial Environment. John Wiley V.C.H., Chichester: 478 p.

Hambrey M., 1994. Glacial Environments. University of British Columbia Press, Vancouver: 296 p. 
Hasholt B., Walling D.E., Owens P.N., 2000. Sedimentation in arctic proglacial lakes: Mittivakkat Glacier, southeast Greenland. Hydrological Processes 14: 679-699.

HewitT K., 2002. Introduction: landscape assemblages and transitions in cold regions. In: K. Hewitt et al., (eds). Landscapes of Transition. Kluwer Academic: Dordrecht: 1-8.

HewitT K., 2006. Disturbance regime landscapes: mountain drainage systems interrupted by large rockslides. Progress in Physical Geography 30: 365-393.

HolLING C.S., 2001. Understanding the complexity of economic, ecological and social systems. Ecosystems 4: 390405.

Howat I.M., Joughin I., TulaczyK S., Gogineni S., 2005. Rapid retreat and acceleration of Helheim Glacier, east Greenland. Geophysical Research Letters 32: L22502, DOI:10.1029/2005GL024737.

ItURRIZAGA L., 2003. The distribution and genesis of lateroglacial valleys in the Karakoram Mountains (Pakistan). Zeitschrift fur Geomorphologie Supplementband 130: 51-74.

ItURRIZAGA L., 2008. Paraglacial landform assemblages in the Hindu Kush and Karakoram Mountains. Geomorphology 95: 27-47.

JoHnson P.G., 1984. Paraglacial conditions of instability and mass movement: a discussion. Zeitschrift fur Geomorphologie 28: 235-250

Jordan P., Slaymaker O., 1991. Holocene sediment production in Lillooet River basin: a sediment budget approach. Geographie physique et Quaternaire 45: 45-57.

LozINSKI W. vON. 1912. Die periglaziale Fazies der mechanischen Verwitterung. Comptes Rendus, XI Congres Internationale Geologie, Stockholm 1910: 1039-1053.

Matthews J.A., ShaKesby R.A., BerRisford M.S., McEwen L.J., 1998. Periglacial patterned ground in the Styggedalsbreen glacier foreland, Jotunheiment, southern Norway: microtopographical, paraglacial and geochronological controls. Permafrost and Periglacial Processes 9: 147-166.

Mercier D., Etienne S., 2008. Paraglacial geomorphology: processes and paraglacial context. Geomorphology 95: 1-2.

Mercier D., 2002. La dynamique paraglaciaire des versants du Svalbard. Zeitschrift fur Geomorphologie 46: 203-222.
Moreau M., Mercier D., Laffly D., Roussel E., 2008. Impacts of recent paraglacial dynamics on plant colonization: a case study on Midtre Lovenbreen foreland, Spitsbergen $\left(79^{\circ} \mathrm{N}\right)$. Geomorphology 95: 48-60.

PenCK A., BRUCKNeR E., 1909. Die Alpen im Eiszeitalter. 3 vols. Tauchnitz, Leipzig: 1199 p.

PHILLIPS J.D., 2003. Sources of non-linearity and complexity in geomorphic systems. Progress in Physical Geography 27: $1-23$.

PutKonen J., Connolly J., OrlofF T., 2008. Landscape evolution degrades the geologic signature of past glaciations. Geomorphology 97: 208-217.

SHAW J., ARCher J., 1979. Deglaciation and glaciolacustrine sedimentation conditions, Okanagan valley, B.C. In: C. Schluchter (ed). Moraines and Varves. Balkema, Rotterdam: 347-355.

SIssons J.B., 1979. The limit of the Loch Lomond Advance in Glen Roy and vicinity. Scottish Journal of Geology 15: 31-42.

Slaymaker O., Kelly R.E.J., 2007. The Cryosphere and Global Environmental Change. Blackwell, Oxford: 261.

Slaymaker O., 2009. Proglacial, periglacial or paraglacial? In: Knight J., Harrison S. (eds). Periglacial and Paraglacial Processes and Environments Special Publication 320. The Geological Society of London: 71-84.

TelLer J.T., 1987. Proglacial lakes and the southern margin of the Laurentide Ice Sheet. In: W.F. Ruddiman, H.E. Wright (eds). North America and Adjacent Oceans during the Last Deglaciation. Geological Society of America, The Geology of North America, v.K-3: 39-69.

Thorn C.E., Loewenherz D.S., 1987. Spatial and temporal trends in alpine periglacial studies: implications for paleo-reconstruction. In: J. Boardman (ed). Periglacial Processes and Landforms in Britain and Ireland. Cambridge University Press, Cambridge: 57-65.

Washburn A.L., 1979. Geocryology: A Survey of Periglacial Processes and Environments. Edward Arnold, London: 406 p.

Wolman M.G., Gerson R., 1978. Relative scales of time and effectiveness of climate in watershed geomorphology. Earth Surface Processes 3: 189-208. 